\title{
Why Does Leadership Exist?
}

\author{
Jay Caulfield \\ Associate Professor, Leadership and Ethics; Associate Dean \\ College of Professional Studies \\ Marquette University \\ Milwaukee, WI \\ Jay.caulfield@marquette.edu
}

\begin{abstract}
What style of leadership is most effective in a particular situation with a specific group of followers? How do leaders best motivate followers in achieving goals? Although important questions, before we may come to fully understand the how and what of leadership, in this brief I suggest that we reflect upon a more basic leadership question. In the context of a paradigm from the work of the late educator and social critic, Neil Postman (1931-2003), I explore the question, "Why does leadership exist?" For when we reflect upon the answer to that question, we may gain further insight into ourselves as leaders, which may enhance our understanding of what good leadership looks like and how we might best achieve it.
\end{abstract}

\section{Introduction}

I have always valued the wisdom of the late educator and social critic, Neil Postman (1931-2003), whose critique of education is quite thought provoking, remaining relevant to this day. It is his work that in part influences my vision of leadership. Postman (1996) believed that before we address questions such as "What should be taught in school?" and "What should be expected of teachers?" we first need to discern the purpose of school, which he proposed was to create morally healthy and sustainable communities. To accomplish this goal of creating community, Postman advocated that teachers must engage students in the exploration of true narratives. In the context of his writing, a true narrative is a complex concept of such significance to our existence as a society that we arrange our lives around it. In the case of true narratives such as democracy and freedom, we risk our lives to attain and preserve them. Other examples of true narratives include love, peace, spirituality, integrity, and learning. Postman believed that 
these true narratives teach us "how to make a life, which is quite different than how to make a living" (p. $x$ ). He further suggests that these narratives provide us with a sense of identity, community, and moral conduct. It is through learning about true narratives that we create the capacity for community building.

\section{Postman's Paradigm in the Context of Leadership Education}

Reflecting on Postman's work in the context of leadership education, it seems that as leaders, researchers, and educators we need to ask a similar question, specifically, "Why does leadership exist?" before we may come to fully understand the how and what questions, which have been the primary focus of the current body of leadership theory and research to date. Some examples of these questions include, "How do leaders persuade others to follow them?" "How do leaders and followers best achieve goals?" "How do leaders best motivate followers in achieving a vision?" "What style of leadership is most effective in a particular situation with a specific group of followers?" I am not suggesting that these questions are not important to the study of leadership. What I am suggesting is that history teaches us that those who we identify as society's greatest leaders had very clear insights on why leadership exists and that is the focus of this writing.

For example, when acting as Commander in Chief of the Continental Army, past President George Washington, was driven in pursuing the true narrative of independence as illustrated by his words, "It is my full intention to devote my life and fortune in the cause [independence from British rule] we are engaged in, if need be" (Phillips, 1997, p. 45).

Another example, Martin Luther King gave his life in the pursuit of freedom; his passion is evident in his words, "We know through painful experience that freedom is never voluntarily given by the oppressor; it must be demanded by the oppressed" (http://teachingamericanhistory.org/library/index.asp?document=100).

These examples and many others suggest that a good part of the answer to, "Why does leadership exist?" has much in common with how Postman poses and answers the question, "Why does school exist?" It could be that the purpose of leadership is to achieve and sustain true narratives that teach us how to make a life while the purpose of schools is to teach students to explore why those narratives are valuable in the first place. Therefore, just as teachers need to engage students in identifying and understanding the relevance of true narratives, leaders need to engage society in pursuing them. 
Those of us in education serve as both teachers and leaders. I would further suggest that global commonality exists in identifying true narratives; how to best achieve and sustain them is where the conflict is likely to arise. For it is the how and what questions that are influenced by cultural norms and divergent life experiences, but the why questions are far more universal and profound, as they are likely to encompass true narratives that are for the most part valued by the majority.

To further illustrate, Washington spent a major portion of his life pursuing independence; yet how Washington practiced leadership in pursuit of independence may have been quite different than how leaders might pursue it today. Culture and context influence leadership, making leadership behavior dynamic over time and circumstance. As Gandhi points out, "I suppose leadership at one time meant muscles; but today it means getting along with people" (as cited in Chew, 2011, p.130.)

However, true narratives that help to identify and explain why leadership exists are timeless. Wise leaders artfully avoid the pitfall of discussing how without first establishing why by linking shared vision to true narratives. For if we agree on why leadership exists, we may then better understand what good leaders need to do to enact it, which, when incorporated into our teaching of leadership, is likely to enhance leadership performance. Many true narratives exist among us. Good leadership recognizes the need to define and redefine those narratives in the context of today's global world, expressing tradition while at the same time vividly painting the narrative in a way that instills passion, creates clarity and engages global minds in contemporary times.

\section{Leadership as True Narrative: Connection, Authenticity, and Vulnerability}

Well-orchestrated leadership is a powerful narrative in itself that profoundly connects us communally in the pursuit of other true narratives, creating in us the heightened sense of identity, community and moral conduct necessary in what Postman describes as making a life. Our heightened sense of identity is the evolving self-discovery achieved through frequent reflection and discernment; it is the sum of who we have become from birth until the present moment. Thus, it becomes vitally important for us to thoughtfully identify those true narratives that are so compelling that they define us and connect us with one another, making us willing to change our life and our work in pursuit of them. For if we let another person or entity define our identity for us, we cheat ourselves out of that true selfdiscovery; and with that, we extinguish the ability to think uniquely and creatively, traits in which most great leaders excel. In other words, we cheat 
ourselves and others out of our best leadership potential. The sacrifices we are willing to make in pursuit of true narratives give us the foundation for making $a$ life and in so doing make our existence more meaningful and worthy in our own eyes as well as in the eyes of those around us.

To better illustrate the importance of connection, the well-known sociologist and researcher Brené Brown (2011), learned from over a decade of research that those of us who feel worthy of belonging (she describes this as whole-heartedness) are those of us who have the courage to be imperfect, the compassion to treat ourselves and others kindly and the ability to feel connected; and that this wholeheartedness is what others describe in us as being authentic. I would argue that successful leadership becomes most apparent at those points in our lives when we are most authentic, when we take the risk to let ourselves be seen, really seen. Brown refers to this depth of authenticity as excruciating vulnerability, which she describes as strength versus weakness; strength that we, as educators, need to demonstrate consistently in our interactions with students and in the work that we do outside of the classroom. It is this degree of authenticity that connects us to one another, and it is those connections that lead to what Postman (1996) describes as making a life by building morally healthy and sustainable communities.

As for authenticity, it is values-based. It is the moral conduct that Postman (1995) describes as necessary when building community. Those of us who consistently though not perfectly emulate espoused values will likely be viewed as worthy leaders. To achieve that depth of authenticity, however, we first need to know ourselves well and be comfortable with that knowledge. In so doing, we are more able to recognize and avoid the pursuit of false narratives, such as excessive consumerism, greed, and illegitimate power over instead of legitimate power with. We learn to realize that serving self above others results in feelings of cynicism, anger, disillusionment, and isolation for us and for those we interact with regularly, including our students. Senge (2002) highlights the importance of authenticity and connection as he writes, "genuine leadership is deeply personal and inherently collective" (p. 359).

\section{Putting Ourselves in the Place of Most Potential}

We might also ask ourselves how we may be most impactful in pursuing true narratives, and in encouraging this pursuit in students as well. Dewitt Jones (2005), a professional photographer, tells us that to best achieve our personal vision in life we need to be in places with the most potential. What I believe Jones means is that we need to develop a keen sense of where our talents and interests are most likely to make a positive difference and that is where we need to place 
ourselves. To illustrate, throughout my career I have seen formal leaders become comfortable in their organizational roles. They have become so comfortable that they begin to use their position power to achieve a personal vision that is unaligned to the organization's vision, sometimes actually convincing themselves that their personal vision is the organization's vision. No matter how honorable that personal vision might be, when it is unaligned with the vision of the organization, it becomes an organizationally ineffective use of talent and resources. Nanus (1992) reminds us of this when he writes, "Human behavior in organizations is very much shaped by a shared vision of a better tomorrow. Developing and promulgating such a vision is the highest calling and truest purpose of leadership" (p. 19).

A classic example of personal vision in conflict with organizational vision can be seen in the behavior of the late Steve Jobs when he parted ways with Apple in the early 1990s. Imagine the passion he felt for the organization he had created from ground up just seven years earlier. And yet he left Apple because his personal vision at his time of departure was unaligned with the company he had founded. That misalignment created barriers instead of bridges and he was smart enough to recognize that what he had created outside of Apple's vision took on a life of its own.

To emphasize, impactful leaders recognize the need to put themselves in the place of most potential by working with those who share the passion of achieving those true narratives most valued by them. Cultural anthropologist Margaret Mead once said, "A small group of thoughtful people could change the world. Indeed, it's the only thing that ever has" (http://www.biography.com/people/margaret-mead9404056). When we align ourselves with those who pursue narratives that we, too, are most passionate about, our chances of achieving success in what we do together is far greater than what we may accomplish alone. We see the truth in this throughout history with examples such as the civil rights movement in the United States, the restorative justice movement in South Africa, the peace treaty attained in El Salvador, and the present sustainability movement across the globe. These historical events clearly demonstrate why leadership exists. In each of these instances, a small group of thoughtful people built their lives around true narratives of equality, peace, preservation, justice, and forgiveness. The impact of their leadership has made the world a better place for all of us.

On a more personal and professional level, we see the power of passion in our teaching and learning, in serving on committees, and in conducting research. When we align ourselves with those in our profession who lead with impact and we do so as well, we put ourselves in the place of most potential for making positive change happen. Challenges begin to present themselves as opportunities for positive change. 
Why does leadership exist? It exists to profoundly connect us to each other in achieving those true narratives that promote the common good by building morally healthy and sustainable local and global communities for the benefit of humanity. Sorenson, Goethals, and Haber (2011) paint this picture as they write, "The human condition, and thus leadership, fundamentally involves making meaning... and that real change...involves influencing the meanings that different groups make in the context of competing and conflicting definitions of reality and of value" (p. 33). In a similar vein, Laudeman (2012) tells us, "In the postmodern world, leading is about contributing to collective cognition and enabling shared sensemaking" (p. 42). When we lead in this way, we continue to discover ourselves and the richness of our relationships with students while role modeling behavior that better illustrates to them why leadership exists. At the same time, we garner better understanding of the purpose of our existence, fulfilling a moral impetus that helps us make a life by pursuing those true narratives that lead to holistically healthy living for us and for those we serve. 


\section{References}

Brown, B. (2011, January 3). The power of vulnerability. [Video file.] Retrieved from http://www.youtube.com/watch?v=iCvmsMzlF7o

Chew, M. (2011). Discover your leadership style. Singapore: Armour Publishing.

Kanopy (Producer) (2005). Everyday creativity. [DVD]. Australia: Producer.

Laudeman, G. (2012). Leading learnership: The transformation of leadership via convergence with learning. In J. D. Barbour, G. J. Burgess, L.L. Falkman, \& R. M. McManus (Eds.). Leading in complex worlds, (pp. 37-62). San Francisco: Jossey-Bass.

Nanus, B. (1992). Visionary leadership: Creating a compelling sense of direction for your organization. San Francisco: Jossey-Bass.

Phillips, D. T. (1997). The founding fathers on leadership. New York: Warner Books.

Postman, N. (1996). The end of education. New York: Random House.

Senge, P. (2002) Afterword. In Greenleaf, R., Servant leadership: A journey into the nature of legitimate power and greatness (pp. 343-360). Mahwah, NJ: Paulist Press.

Sorenson, G., Goethals, G. and Haber, P. (2011). The enduring and elusive request for a general theory of leadership: Initial efforts and new horizons. In A. Bryman, D. Collinson, K. Grint, B. Jackson, \& M. Uhl-Bien (Eds.). The Sage handbook of leadership (pp. 29-36). Washington DC: Sage. 


\section{Author Biography}

Jay Caulfield, Ph.D., as Associate Dean, Dr. Caulfield has led the curriculum design of the college's graduate degree in leadership studies. She routinely teaches courses in leadership theory, research methods and qualitative research. She serves on numerous university and college committees and boards including the University Board of Graduate Studies, the Institutional Review Board, and currently chairs the University Committee on Teaching. In spring of 2011, she received an outstanding service award from the College of Professional Studies for her teaching, service, and research. She is a member of the International Leadership Association and the International Society for the Scholarship of Teaching and Learning. 